\title{
The historical origin of the Pulfrich effect: a serendipitous astronomic observation at the border of the Milky Way
}

\author{
Axel Petzold* $\quad$ Eckhart Pitz ${ }^{\dagger}$
}

November 3, 2008

\begin{abstract}
Interested in star movement the Founder of Heidelberg's astronomy observatory, Max Wolf, faced the dilemma that the hitherto used 'Blinkmikrosop' of his Institution was damaged beyond repair following the first world war. He therefore used a new method, stereoscopy, to systematically classify 1053 moving stars between 1915 and 1918 . The key problem Wolf identified with the new method was that variation in brightness of the same star on different photographic plates gave rise to an illusory movement. This was a particularly frequent problem with smaller stars close to the very bright Milky Way such as those in the proximity of Cygni or "fadeout stars" such as R Coronae Borealis. Carl Pulfrich, the world leading expert on stereoscopy at the time, picked up immediately on the technical limitations Wolf published on stereoscopy in 1920. Pulfrich, who was blind on one eye, could not see the effect himself and designed a projection device to demonstrate Wolf's serendipitous observation to an audience which was equipped with a monocular neutral density filter. Pulfrich performed detailed investigations on the relationship of spatial perception and object movement, naming the phenomenon "stereo effect", but it became widely known as the 'Pulfrich effect'. The neuro-anatomical basis of the Pulfrich effect lies in the joint encoding of motion and depth within the visual cortex. Recognising Pulfrich effect is relevant for the management of patients in whom pathology of the visual pathways impairs judgement of object movement/position (e.g. in traffic or sport). Fitting a unilateral tinted lens or contact lens in front of the good eye can abolish the problem.
\end{abstract}

\footnotetext{
*Corresponding author: Department of Neuroimmunology, Institute of Neurology \& The Tavistock Intensive Care Unit, The National Hospital for Neurology and Neurosurgery, Queen Square, London, WC1N 3BG, United Kingdom. Fax: +44 207837 8553, E-mail: a.petzold@ion.ucl.ac.uk

†Max-Planck Institute für Astronomy \& ZAH Landessternwarte Königstuhl 12, 69117 Heidelberg, Germany.
} 


\section{Keywords}

\section{Introduction}

\section{Carl Pulfrich}

In 1920 Carl Pulfrich (Figure 1) came across a publication which alerted him to a potentially fundamental flaw in a method he had spent the past 25 years developing: quantitative stereoscopy [1]. The comment published by the influential astronomer Max Wolf (Figure 2) implied that this methodological problem could make any attempt of precise measurements futile. If true this could threaten the expanding market for stereoscopic instruments on which the Carl Zeiss company held a quasi monopoly.

Carl Pulfrich was employed by Carl Zeiss and developed stereoscopy from being an entertainement, creating illusory 3D effects from photographs to a powerful quantitative technique. His apparatus to measure distances stereoscopically was presented in Munich in 1899 and his stereo-comparator in Hamburg in 1901 (Figure 4A). Stereoscopy had already been used in topographic geography, astronomy studies and increasingly by the Marine. With stereoscopy everything could be done quicker and with a higher degree of precision. At the time Pulfrich became aware of Wolf's observation, attempts were being made to use stereoscopy from planes for topographic purposes. Pulfrich was certainly fully aware of the stakes at risk if his relatively new method should be flawed.

\section{Max Wolf}

Max Wolf (Figure 2) was born on the 21st of June 1863 to the Heidelberger physician Dr Franz Wolf [2]. His interest in stars started in boyhood and at the age of 16 years he started to observe them seriously. His father supported Max's interests and together they built an observatory in their back garden in the Märzgasse in Heidelberg. There, only 20 years old, Max Wolf discovered a new comet in 1884 and his career path was set. He obtained his $\mathrm{PhD}$ in his native Heidelberg. After a one year post-doctorate period in Stockholm he was promoted to reader (Privatdozent) of the Heidelberg University in 1890, Extraordinary Professor in 1893 and Ordinary Professor of astronomy in 1902. He was the founder and first Director of the observatory in Heidelberg Königstuhl. Thanks to a $\$ 10,000$ donation by the American philanthropist Miss Bruce, Wolf was able to purchase excellent equipment for his observatory and in turn named his main telescope the "Bruce telescope". Wolf was a phenomenal worker and discovered thousands of nebulae, galaxies, the movement of spiral galaxies, the first Trojan asteroid (Achilles), proved the existence of clouds of dark matter and was a pioneer of astrophotography. Amongst his many credentials were the Gold Medal of the Royal Astronomical Society in 1914 [3] and the 25th Bruce Medal in 1930 [4]. A lunar crater and a planet 
(\#827) beare his name and one external galaxy he discovered in 1909 is now known as the "Wolf-Lundmark-Melotte" (WLM) Galaxy.

\section{A serendipitous observation}

Wolf pioneered using the stereo-comparator (Figure 4B) in combination with photography to systematically survey the night sky. In part he had to resort to the new method because the gold standard at the time, the Blinkmikroscope of his Institution, was damaged and the war (1914-1918) made it impossible to repair it. In addition, he realised that using photography in combination with new fast lenses would enable him to discover new star formations more quickly. One of the stars which attracted his attention was a small star next to $\alpha_{2}$ Cygni (Deneb). Deneb is the prototype of $\alpha_{2}$ Cygni variables in which variations in brightness of 0.1 magnitudes are associated with radial pulsations. For Deneb the brightness fluctuates between magnitudes of 1.21-1.29. Wolf states in his paper "In mehreren Fällen (z.B.in der Gegend von $\alpha_{2}$ Cygni, Veränderlicher Nr. 19) war ich lange Zeit im Zweifel ob nicht doch Eigenbewegung vorlag. (In some instances (eg in the region of $\alpha_{2}$ Cygni, variable number 19) I was in doubt for a long time as to whether or not the star moved)." [5]. A key problem Wolf identified with stereoscopy was that variation in object brightness hindered precise measurements, potentially making any attempt of quantification futile (Figure 3 [5]).

Figure 5 illustrates this problem. A moving star visible to the reader is shown on two images taken by Max Wolf 14 years apart (Figure $5 \mathrm{~A}$ ). The difficulty in obtaining equally illuminated plates from a slightly busier section of the sky is illustrated by two images taken in the same night (Figure 5B). Finally, the problem Max Wolf observed is illustrated by the visible pulsating yellow supergiant $\mathrm{R}$ Coronae Borealis (Figure $5 \mathrm{C}$ ). This star is bright in one image and faded in the other, against an unequally illuminated background from a very busy section of the night sky. Using the stereo-comparator (Figure 4B) it was not possible to measure movement with confidence because of the Pulfrich effect.

\section{Discovery of the Pulfrich effect}

Pulfrich had to take the observations made by Wolf in 1920 seriously. He conducted a number of experiments with the help of two colleagues Franke and Fertsch, showing that the key problem was a difference in brightness between the photographs. He gave full credit to Fertsch for suggesting that this could be explained if the movement of the brighter object were perceived earlier than the movement of the darker object [1]. Pulfrich was particularly intrigued by his colleagues noting that the impression was that of a circular movement.

Unfortunately Pulfrich was unable to observe this himself because he had lost sight in his left eye about 16 years earlier, a late sequel of an accident in his youth. In order to circumvent the problem he developed a projector which 
could be used to illustrate the effect to an audience using one moving and one fixed pointer (Figure 6). A simple trick enabled him to simulate different brightness, he asked his audience to hold in front of one eye a neutral density filter ("Rauchglas") of the sort still in use today when observing the sun during an eclipse. With the neutral density filter in front of the left eye a straight left to right movement of the free pointer (top in Figure 7) would appear to pass behind the fixed pointer (bottom in Figure 7). Conversely a right to left shift would give rise to the illusion that the moving pointer passed in front of the fixed pointer. The effect became stronger with increased velocity and disappeared abruptly when the pointers were stopped.

Pulfrich produced a number of diagrams, one of which showed the linear relationship between the speed of pointer movement and spatial offset (Figure 8 right). He also showed that the shape of the curves became irregular and therefore less predictable if the velocity of the moving pointer changed (Figure 8 left). Pulfrich had already realised from the reaction of some of his study subjects, that people in whom visual function differed between both eyes perceived this stereo-effect: "Gibt es doch, wie sich jetzt herausgestellt hat, Personen, die auch im freien Sehen das Kreisen der Marke sehen, links oder rechts herum, je nachdem bei dem betreffenden Beobachter das linke oder das rechte Auge schneller reagiert als das andere. In solchen für den Augenarzt besonders beachtenswerten Fällen konnte jedesmal eine mehr oder weniger grosse, durch einseitigen Gebrauch oder andere Ursachen erworbene Ungleicheit der beiden Augen nachgewiesen werden. (There are, as we have found out, people who can perceive the circulation of the pointer without using a neutral density filter. The left- or rightward movement depends on whether the observer's left or right eye reacts quicker than the other. In these cases, relevant to the ophthalmologist it was always possible to demonstrate a difference between the two eyes, due to unilateral use (Translator's remark: Pulfrich refers to amblyopia) or other causes.)". Pulfrich almost spells out the diseases in which this phenomenon can occur. He wonders for an instant why this effect has not already been noted, particularly as there are swinging pendulums in every shop selling clocks ("Wenn man bedenkt mit welch einfachen Mitteln die Erscheinung der kreisenden Marke hervorgerufen werden kann, so kann man sich nur darüber wundern, dass sie anscheinend nicht schon früher einmal beobachtet worden ist, wozu doch jeder Uhrenladen die Gelegenheit bietet. (If one considers the simple means used to produce the phenomenon of the circulating pointer, one wonders why this observation has not been made earlier, particularly as every shop selling clocks offers this opportunity.)") [1].

\section{The Pulfrich effect today}

The Pulfrich effect captured the attention of the masses through television (TV) when it was used in the 1993 Doctor Who charity episode Dimensions in Time. The TV viewers were equipped with a paper frame containing a neutral density (transparent grey) filter on one side and transparent foil on the other. The 
Pulfrich effect was particulary popular in the Netherlands where 3D clips were shown on TV and glasses sold on gas stations across the country. Over six million glasses were sold in the US to the viewers of Shark Week on the Discovery channel in 2000.

Using extracellular recordings from single neurons in the cat striate cortex, Anzai and colleagues demonstrated the neuro-anatomical basis of the Pulfrich effect to be due to joint encoding of motion and depth [6]. As expected from these findings, a monocular counterpart of the Pulfrich effect occurs with monocular visual field defects and Lars Frisen coined the term lazy shadow phenomenon [7].

Clinically, recognising the Pulfrich effect is relevant to patient management. Patients who suffer from optic neuritis may notice the Pulfrich effect in the recovery phase. These patients describe difficulties with perception of depth for moving objects. As one can predict from Figure 8 this becomes more of a problem if the velocity of the objects varies, typical in moving traffic. Patients may be unable to drive a car, bicycle or even feel insecure walking on the pavement or navigating through busy shopping malls. Other problems include misjudging the object trajectory in tennis, squash, etc. Patients may also miss a glass whilst attempting to pour liquid into it. Using a key they may initially miss the keyhole. Generally judging height and width is a problem (e.g. with stairs or doors as well as placing objects).

The Pulfrich effect can occur with any condition causing unilateral or asymmetric damage to the visual system. The Pulfrich effect has been studied in traumatic injury to the optic nerve, ischaemia, asymmetric cataract or unilateral lens capsule thickening after cataract surgery, glaucoma and with a unilateral dilated pupil. The treatment consists of the use of a tinted lens or contact lens in front of the better eye. The symptomatic relief is immediate and long-term in stable conditions [8].

\section{Acknowledgements}

We would like to acknowledge the generous contribution of the Landessternwarte Heidelberg for allowing us to reproduce the photographs of Max Wolf, the facsimile of his manuscript and his photographic plates. We are very thankful to MrG Klare, Mr K Birkle and Mr H Mandel for their help in locating and digitising the historical photographs as well as retrieving Max Wolf's diary entry used to describe Figure 5. We are thankful to the Carl Zeiss archives for permission to reproduce the photograph of Carl Pulfrich. The International Astronomic Union (IAU) named one asteroid (\#827, Wolfiana) after Max Wolf and the success of discovering more asteroids with these new methods is illustrated by the increase of numbering within only one generation (\#19182, Pitz). 


\section{References}

[1] C Pulfrich. Die Stereoskopie im Dienste der isochromen und heterochromen Photometrie. Naturwissenschaften, 10:553-564, 1922.

[2] H MacPherson. Orbituary Max Wolf. Observatory, 55:355-359, 1932.

[3] EH Hills. Delivered by the President, Major E. H. Hills C.M.G., D.Sc., F.R.S., on presenting the Gold Medal of the Society to Dr. Max Wolf. Monthly Notices of the Royal Astronomical Society, 74:377-390, 1914.

[4] FH Seares. Address of the retiring president of the Society in awarding the Bruce Medal to Professor Max Wolf. Publications of the Astronomical Society of the Pacific, 42:5-22, 1930.

[5] M Wolf. Veröffentlichungen der Badischen Sternwarte zu Heidelberg. 7(10):196-198, 1920.

[6] A. Anzai, I. Ohzawa, and R. D. Freeman. Joint-encoding of motion and depth by visual cortical neurons: neural basis of the Pulfrich effect. Nat Neurosci, 4(5):513-8, 2001.

[7] L. Frisen. The lazy shadow: a monocular counterpart to the Pulfrich stereo phenomenon. Br J Ophthalmol, 91(10):1296-8, 2007.

[8] G. Heron, K. J. Thompson, and G. N. Dutton. The symptomatic Pulfrich phenomenon can be successfully managed with a coloured lens in front of the good eye-a long-term follow-up study. Eye, 21(12):1469-72, 2007. 


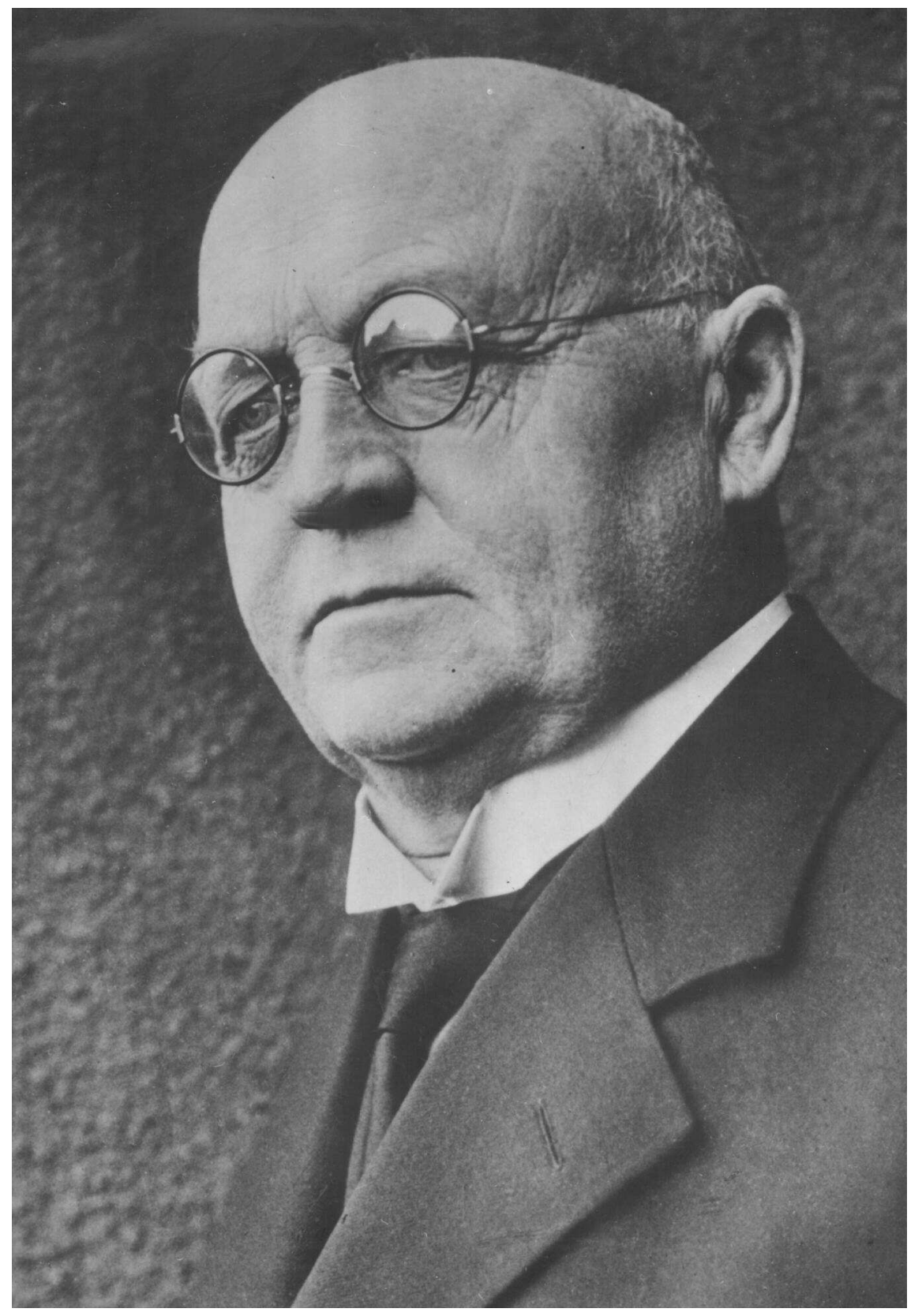

Figure 1: Carl Pulfrich, * 24.9.1858 Düsseldorf, Germany; $\dagger 12.8 .1927$ Baltic Sea, drowned when his canoe capsized. 


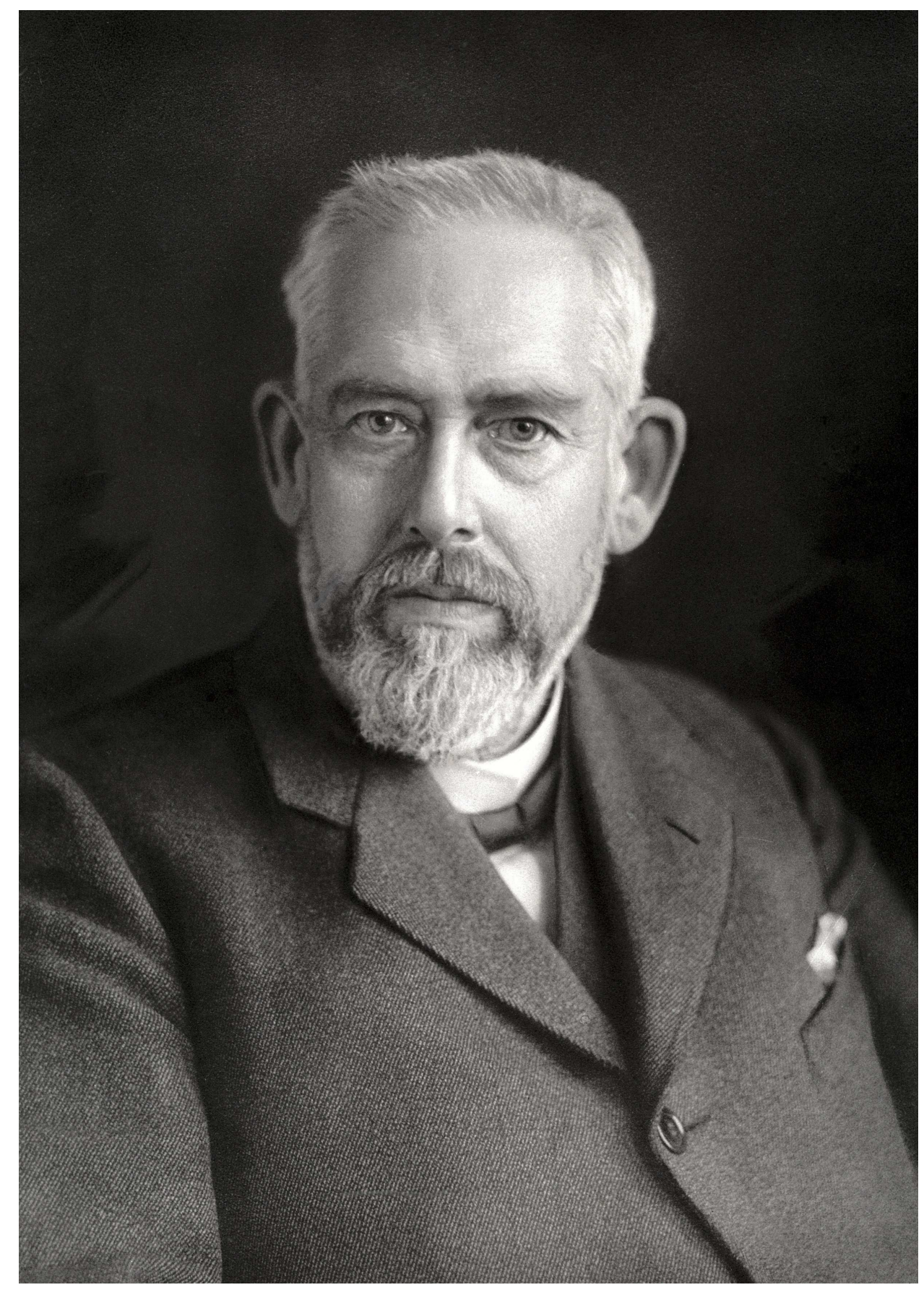

Figure 2: Maximilian Franz Joseph Cornelius Wolf, * 21.6.1863 Heidelberg $\dagger 3.10 .1932$ Heidelberg. Photograph taken from the original which can be seen in the library of the astronomic observatory in Heidelberg (Heidelberg 16.08.2008). 


\section{VERÖFFENTLICHUNGEN \\ DER \\ BADISCHEN \\ STERNWARTE ZU HEIDELBERG \\ (KONIGSTUHL)}

BAND 7 , No. ro.

\section{Katalog von 1053 stärker bewegten Fixsternen.}

Von Max Wolf.

\section{(B)}

2. Die Hauptschwierigkeit der Bestimmung beruht auf der verschiedenartigen Bildform der Sterne auf den beiden verglichenen, zeitlich verschiedenen Aufnahmen. Aus diesem Grund ist man auch gezwungen, sich an möglichst gleich helle Sterne als Referenzsterne und an die nachste Umgebung zu halten. Nur so hat man ăhnliche Bildform. Bei den kurzbrennweitigen Linsen des Bruce-Fernrohrs ist es nur selten der Fall, daB die Bilder selbst an gleichen Stellen der Platten und bei gleicher Belichtung genau gleich ausfallen. Die verănderte Fokussierung, verbunden mit Biegung und Differentialrefraktion einerseits, die variable Empfindlichkeit der Plattensorte und die Belichtung andererseits machen eine Wiederholung gleicher Bildform zu einer großen Seltenheit. Ganz ausgeschlossen war aus den genannten Ursachen ein Bezichen der Bewegung auf den sGrunde der ganzen Gegend.

In diesen Störungen liegt die Schwäche der Methode, die natürlich jeder anderen photographischen Methode gleicherweise anhaftet. Ja, die geänderte Bildform verhindert in vielen Fallen jede genauere Messung; manchmal sogar jede Messung überhaupt.
(C)

Letzterer Fall tritt häufig ein, wenn die Bilder strichformig erzeugt werden zur Aufsuchung schwacher Planeten oder Kometen; und besonders häufig bei der verzerrten Bildform des Reflektors. Fs kommt in Milchstraßengegenden öfter vor, daß man einen Stern sschweben s sieht und ihn fur bewegt halten möchte, wo sich schließlich bei genauer Proflung zeigt, daB ein unmittelbar anhaftender, schwacher Veranderlicher der Schuldige ist und den Stern sbewegte hat. Ja, es ist sehr wohl möglich und bei mir vielleicht auch vorgekommen, dab man die Bewegung eines solchen Sterns für reell halt und vermißt, wenn man nicht die gentigende Anzahl verschiedenzeitlicher Aufnabmen zur Verfügung hat. In mehreren Fallen z, B. in der Gegend von $\pi_{2}$ Cygni, Veränderlicher Nr. Ig) war ich lange Zeit im Zweifel, ob nicht doch Eigenbewegung vorlag.

3. Jemandem, der Schlasse ziehen wollte ans der Anzahl der entdeckten Figenbewegungen der Stetne verschiedener Helligkeit: auf GesetzmaBigkeiten in der Verteilung der Eigenbewegungen bei verschiedenen Größenklassen, muB ich zu gröBter Vorsicht raten. Es hat sich

Figure 3: Photographic reproduction and translation of the original text from Wolf [5]. (A) Page 195, the limitations of stereoscopy as a method for investigating the movement of stars is reflected in the title where it reads "Catalogue of 1053 stronger (Translator's remark: meaning "a wider range of movement") moving fixed stars". (B) Page 196, Wolf discusses the numerous limitations of stereoscopy, concluding "These interferences define the limitations of the method, which is inherent to all other photographic methods. Indeed the change in the appearance of the picture frequently hampers exact quantification; occasionally making it impossible to measure at all.". (C) Page 196, Wolf refers to his observations close to the Milky Way: "It happens that in the area of the Milky Way one perceives a star 'floating' and interprets that as movement...", "that one perceives the movement of such a star as real ...". He gives one example "(eg in the region of $\alpha_{2}$ Cygni, Veränderlicher no 19). I was in doubt for a long time as to whether or not the star moved.". Finally he warns others not to over-interpret their observations if they use stereoscopy "To someone who would like to draw conclusions on the discovered self-motion of stars of different brightness ... I advise the utmost caution.". 

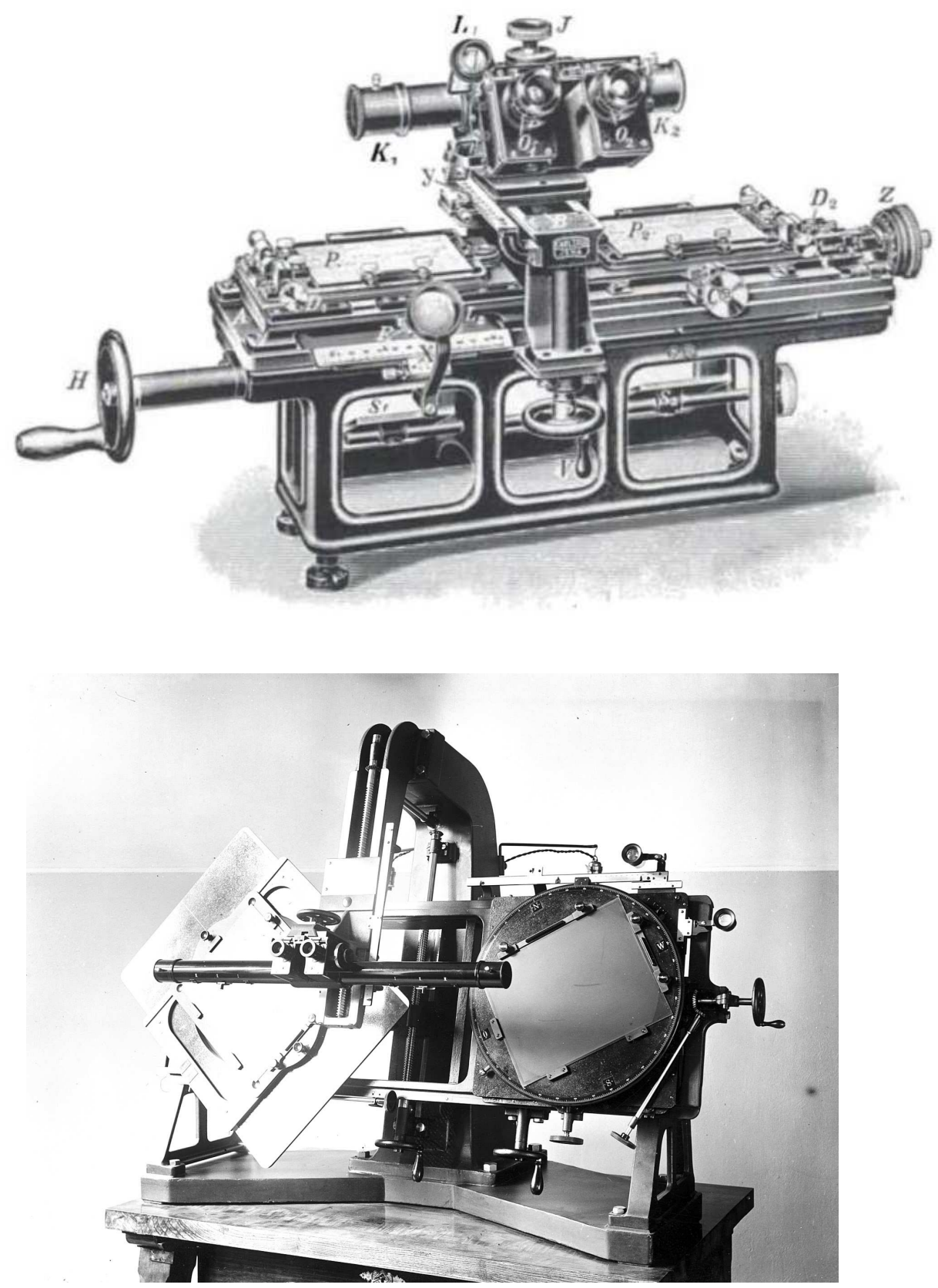

Figure 4: (A) Pulfrich's stereo-comparators used two photographic images ("Platten") positioned at " $P_{1}$ " and " $P_{2}$ ". It allowed for topographic point to point quantification. The instrument was used in geography for urban measurements. (Reprinted from reference [1]) (B) For use in Astronomy Max Wolf codeveloped a stereo-comparator with Carl Pulfrich. Max Wolf used the stereocomparator shown in the photograph for his observation. The two mounted photographic plates of the night sky would be illuminated from behind and the observer would gaze through the binoculars on these images (Photograph taken on the 19.09.2008). 

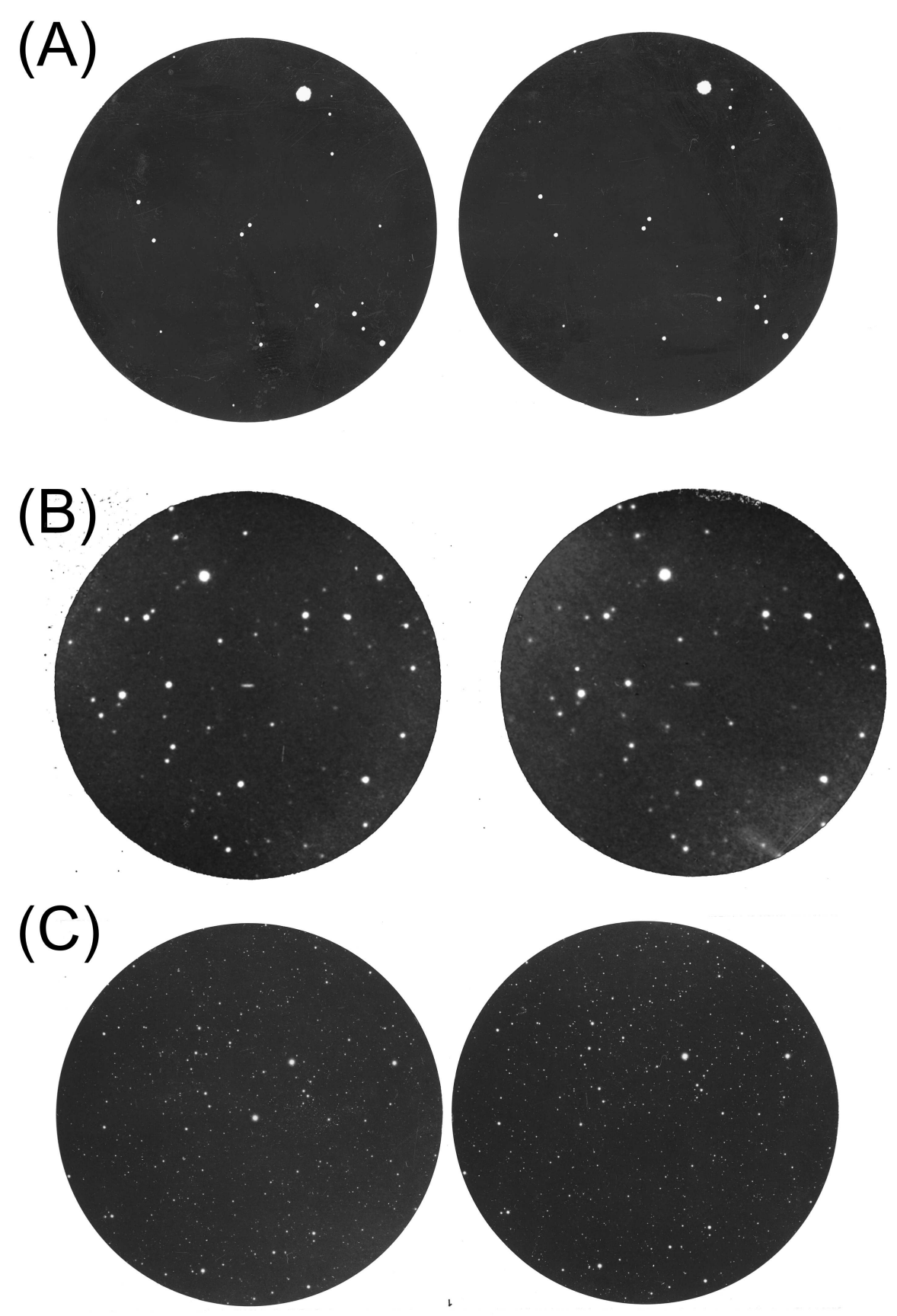

Figure 5: Three photographic plates illustrating the problem. (A) a straightforward situation with a dark background from the constellation of Leo. The left image was taken on the 25th March 1892 and the right image 14 years later on 4th March 1906. One of the two stars in the middle of the photographic plate changed position by 19.6 seconds of arc south (ie to the right in the image). (B) Illustrates the difficulty getting two edually illuminated plates. The line in the middle of the image is caused by movement of a planet (Svea, no 329). Both images were taken on the 21st March 1892 with a two-hour exposure but the right image is brighter. (C) Shows an example where the stereo-phenomenon occurs. The high density of bright stars and the different brightness of the background illumination make accurate measurements difficult. The variable star $R$ Coronae Borealis $(R \mathrm{CrB}$ ) seen in the middle of the left plate lost brightness in the right image. His nicknames are "Fade-Out star" and "Reverse Nova". Thus Pulfrich effect occurs if $R \mathrm{CrB}$ is visualised in the stereo-comparator. 


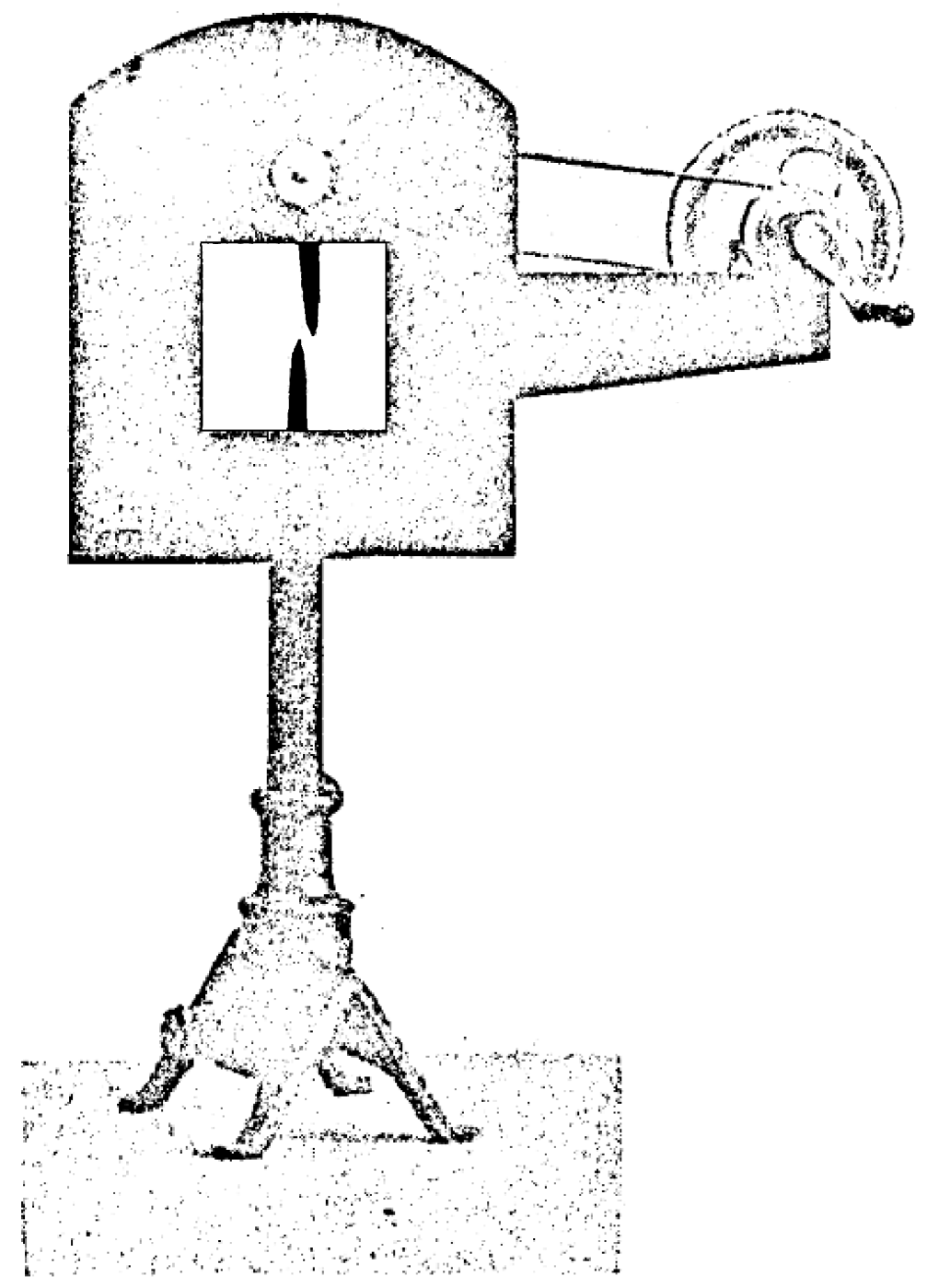

Fig. 3. Hilfsapparat A für die Demonstration des Stereo-Effektes im Auditorium.

Figure 6: Pulfrich used this projector to illustrate the Pulfrich effect to the public. The bottom pointer was fixed and the top pointer was moved by cranking the handle. 


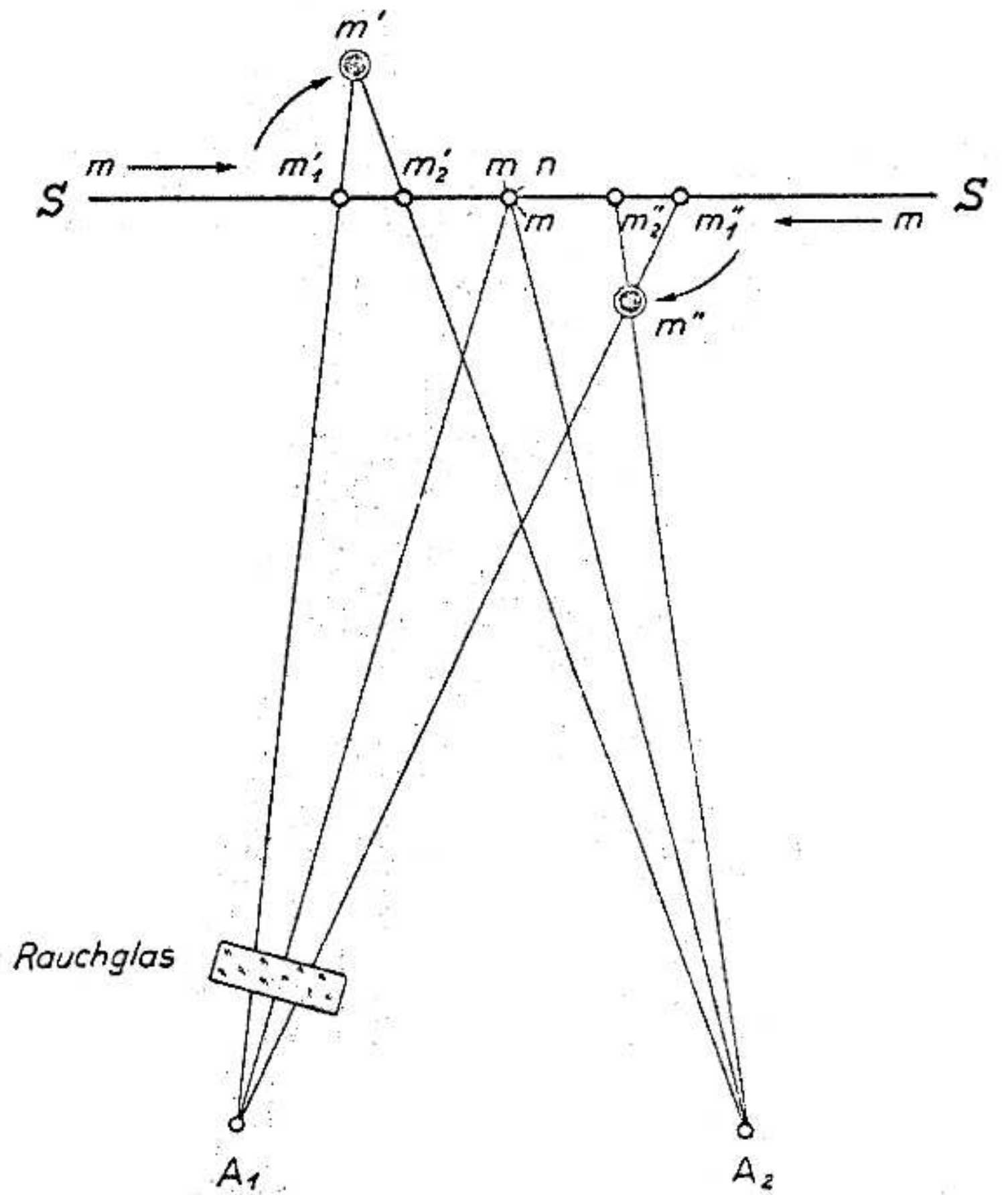

Fig. 5. Wie das Kreisen der Marke zustande kommt.

Figure 7: The classical explanation of the Pulfrich effect. A neutral-density filter ("Rauchglas") is held in front of the observer's left eye $\left(A_{1}\right)$. This results in time delay for the retinal signal to reach the visual cortex. Consequently, the perceived position of the pointer in the left eye $\left(A_{1}\right)$ falls behind that in the right eye $\left(A_{2}\right)$ at a given moment $\left(m_{1}, m_{2}\right)$, creating a spatial offset between the images perceived in the two eyes. If the pointer moves from left to right the spatial offset corresponds to a binocular disparity that shifts the perceived depth of the pointer away from the observer (black dot $m^{\prime}$ ). If the pointer moves from right to left the perceived depth of the pointer shifts towards the observer (black dot $m^{\prime \prime}$ ). 


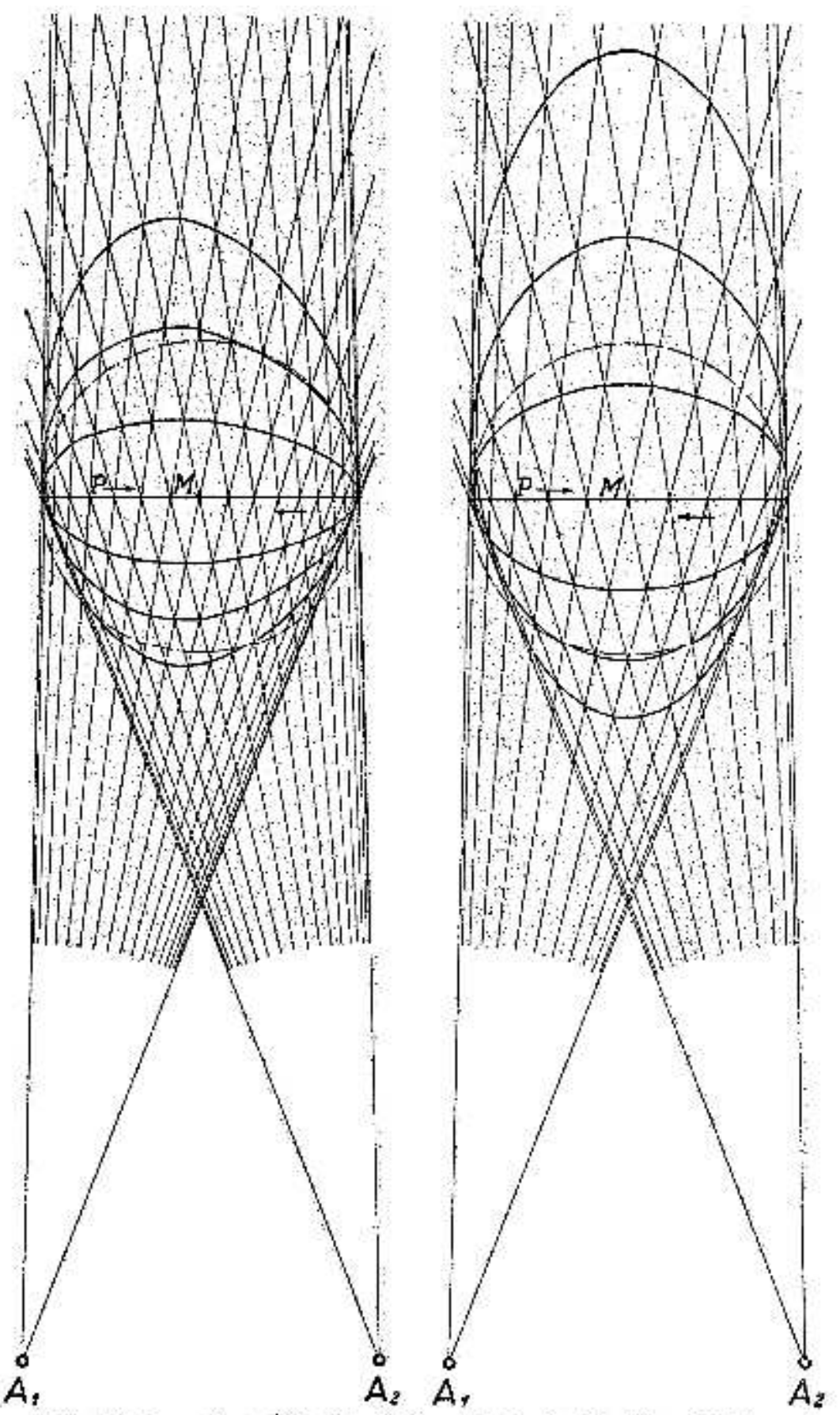

Fig. 7. Kuroen gleioher Zeitparattaxept ful den Fall, dab der Punkt $x$ it der ghene der beiden Blöek-

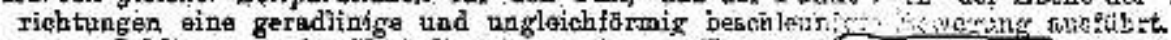
SchLitten war far Kirbelbetriob $(l: 5-37$ Rinfurios Sinusbewegung

Figure 8: The time delay after stimulation of the corresponding points in two eyes by a moving object. The left side of the Figure shows the perceived shift in depth with a irregular movement if the handle is very small compared to the radius $1: 3=3$ (l=length of handle, $r=$ radius of turning wheel). The right side of the Figure shows that with a very large handle an almost regular sinusoid movement becomes possible $(I: r=\infty)$. 